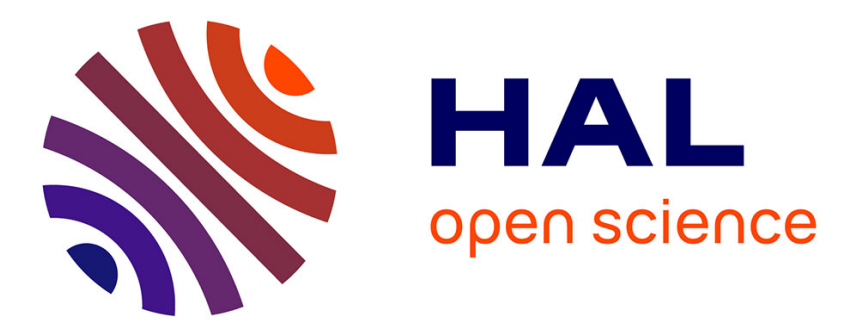

\title{
Competition and Credibility of Private Third-party Certification in International Food Supply
}

\author{
Sven Anders, Diogo Souza-Monteiro, Elodie Rouviere
}

\section{To cite this version:}

Sven Anders, Diogo Souza-Monteiro, Elodie Rouviere. Competition and Credibility of Private Thirdparty Certification in International Food Supply. Journal of International Food and Agribusiness Marketing, 2010, 22 (3-4), pp.328-341. 10.1080/08974431003641554 . hal-01323238

\section{HAL Id: hal-01323238}

\section{https://hal-agroparistech.archives-ouvertes.fr/hal-01323238}

Submitted on 30 May 2016

HAL is a multi-disciplinary open access archive for the deposit and dissemination of scientific research documents, whether they are published or not. The documents may come from teaching and research institutions in France or abroad, or from public or private research centers.
L'archive ouverte pluridisciplinaire HAL, est destinée au dépôt et à la diffusion de documents scientifiques de niveau recherche, publiés ou non, émanant des établissements d'enseignement et de recherche français ou étrangers, des laboratoires publics ou privés. 


\title{
Competition and Credibility of Private Third-party Certification in International Food Supply
}

\author{
Sven Anders \\ Diogo Souza-Monteiro \\ Elodie Rouviere
}

\begin{abstract}
With globalization a number of international food standards and certification systems emerged in in modern food supply chains. Thirdparty certifiers are critical institutions and play a pivotal role on quality assurance and they provide sound and reliable information on productôs quality and safety attributes. Private certification systems can only provide credible market signals if they are objective and independent. This paper investigates the potential implications of increasing certifierôs competition on the credibility of private food standards. Our results indicate that increasing economies of scale and certifier market shares are important determinants of third-party certifier competition.
\end{abstract}

KEYWORDS. Third-party certification, market structure, international food marketing, EurepGAP

Sven Anders is Assistant Professor, Department of Rural Economy at the University of Alberta, Canada; Diogo Souza-Monteiro is Assistant Professor, Applied Economics and Business Management at Kent Business School, University of Kent, United Kingdom; Elodie Rouviere is $\mathrm{PhD}$ Candidate, INRA MOISA at University of Montpellier I, France. Address correspondence to: Sven Anders, Department of Rural Economy, 515General Services Building, University of Alberta, Edmonton, Alberta T6G 2H1, Canada (E-mail: sven.anders@ualberta.ca). 


\section{Competition and Credibility of Private Third-party Certification in International Food Supply}

\section{INTRODUCTION}

High-quality foods markets have changed dramatically along the past twenty years and moreover with the advent of the new millennium. A plethora of food-safety breakdowns diminished consumersôconfidence and trust in the ability of the agro-food industry and governmental authorities to assure the provision of safe and high quality foods. Increasing vertical coordination in food supply chains has triggered a shift in structures from single firm to multi-stakeholder supply-chain configurations (Barkema and Drabenstott, 1995). A particularly critical issue of this new paradigm of food supply is the emergence of opportunistic behaviour associated with information asymmetries between contracting parties.

Credible quality signalling is a pivotal element facilitating transactions among agents in the food chain. Reliable product information becomes even more important when firmsô differentiation strategies involve credence attributes such as food safety, organic farming or fair trade. Shifts in governmental consumer protection strategies, stricter private food quality and safety standards place greater responsibility on food suppliers, especially retailers, who are becoming ñgatekeeperôsò and guarantors of food quality and safety. This is certainly the case in the UK where the Food Safety Act of 1990 requires a stricter control of production and processing 
along the supply chain and forces retailers to assume their share of responsibility on the provision of food safety (Henson and Northen, 1998). Across Europe, retailers are adapting to a new market and regulatory environment, developing and imposing quality assurance systems on their suppliers [Fulponi, 2006; Henson, 2006]. The main motivation for these strategies is the assurance of food safety and quality and liability mitigation (Hatanaka, Bain and Busch, 2005). These control systems reassure governmental authorities and consumersô on the quality and safety of products. In recent years several new control and certification bodies have emerged. Thus, new markets have evolved where third-party certifiers (TPC) compete to provide food quality and safety certification services for different private or public food standards, from good farming practices to processor specifications in various standards.

This paper focuses on the third-party certification market. Increasing demand for independent private third-party certification of quality assurance schemes creates incentives for market entry of new firms, thus affecting the level of competition among accredited certifiers. Our goal is to investigate the impact of structural change in the TPC market by addressing the issue of market competition as it can affect the accuracy of certification procedures and thus the credibility of private food standards altogether.

Third-party certifiers (TPC) have evolved as independent and credible institutions designed to ensure quality and safety standards across food 
markets. Third-party certification is one way to assess and to monitor firmôs compliance with standards, practices, principles, and/or legal requirements. Certification can be defined as a voluntary assessment of and approval by an accredited party and an accredited standard (Meuwissen et al., 2003). Product and/or process certification may reduce uncertainties and lower overall transaction costs that arise from information asymmetries between producers and retailers in vertical supply chains [Caswell et al., 1998; Tanner, 2000; Deaton, 2004; Manning and Baines, 2004].

Busch et al. (2005) and Tanner (2000) point out that the credibility of third-party certification critically depends on the objectiveness and independence of the certifier. As market entry alters the competitive structure in the TPC market, there may be a linkage between the accuracy of TPCs and market structure as competition stiffens (Lizzeri, 1999). If this is the case, the role of TPCs as an efficient signalling institution may be challenged [Carriquiry, Babcock and Carbone, 2003; McCluskey, 2000].

The paper is organized as follows: Section two provides an overview of the economics of third-party certification with an emphasis on recent work and its implications on food markets. Section three proposes an analytical framework relating the structure of the TPC market to the objectivity of the certification process. The fourth section presents an empirical case study using panel data on the Euro-Retailer Produce Working Group Good 
Agricultural Practices (EurepGAP) quality assurance system in the international fruits and vegetables market. Finally, conclusions are drawn.

\section{THE EMERGENCE OF THIRD-PARTY CERTIFIERS AND THEIR}

\section{ROLE IN FOOD CHAINS}

According to neo-classical economic model, both suppliers and buyers in the market are fully informed about the homogenous commodity that is exchanged. The reality of todayôs global food markets, however, is characterised by highly diversified products and far reaching information deficits on both side of the market [Jahn, Schramm and Spiller, 2005; Busch and Bain, 2004]. Empirical studies on food markets suggest that third-party certifiers may mitigate market failure due to information asymmetries between market participants. For instance, Caswell et al. (1998) argue that third-party certification may reduce transactions costs where uncertainty about product quality attributes exists. Carriquiry, Babcock and Carbone (2003) investigate the relation between the stringency of TPCs and optimal quality systems in terms of agricultural output. They find that credible signals in the market place critically depend on the ability of TPCs to establish a positive reputation for its certification service.

While public authorities enforce quality and safety standards through laws and regulations, private agents managing quality assurance schemes punish non-compliance by refusing to issue conformity signals. However, certifiers typically follow some form of economic profit-maximisation rule 
and the payment of their services is somewhat dependent on quantities of product certified that conforms to the standard. This is an important difference and should not be ignored (Jahn, Schramm and Spiller, 2005). The analysis of private TPCs has to acknowledge the existence of opportunistic behaviour which may hinder the efficiency and effectiveness of TPC in providing quality signals.

Tirole (1986) offers important insight into the importance of independence of the third party in transaction processes. His seminal paper uses principal agent theory to model the behaviour of three parties (principal, agent and supervisor) in an organization viewed as a network of intertwined contracts. He shows that, with a dependent third party, coalitions may emerge that prevents a free and efficient flow of information between market partners. Thus, the market structure needs to be considered when analysing TPC markets. Using game theory, Lizzeri (1999) studies the impact of market structure on the process of gathering and revealing information. He shows that if the TPC is a monopolist, it will reveal only part of the available information creating a monopoly rent and decreasing social welfare. Contrarily, under a perfectly competitive TPC market, all private information is revealed and social welfare is optimal.

Manning and Baines (2004) stress the importance of certifier accreditation through independent institutions to assess and ensure certifier independence and objectiveness of the certification procedures offered. The 
authors claim that accredited TPCs offer more guarantees of independence, impartiality, competence and sustainable performance to consumers or other stakeholders. However, accreditation is a largely formal process that does not include the actual monitoring of the certification procedure.

To date, researchers have gained a limited understanding of the quality and thoroughness of control procedures and the determinants that may trigger opportunistic behaviour and/or the creation of market entry barriers. Jahn, Schramm and Spiller (2005) note that institutions that assure ćontrolof-controlômechanisms are imperative to many of todayâ private agrifood certification systems. A lack of ácontrol-of-controlô may otherwise create environments with strong incentives for incumbent TPCs to prevent market entry of new competitors in a rapidly growing certification market with evolving regulations. In addition, TPCs established in the food sector may find it easier to achieve accreditation for multiple industries realising economies of scale that create added entry barriers for newcomers to the market.

Deaton (2004) analyses the role of TPCs using an information economics framework. Under the assumption of independent TPCs, Deaton shows that certification will only provide effective market signals if low quality producers face higher certification costs than high quality suppliers. Given the competitive pressure that is common to many retailer-led food supply chains, suppliers may view product or process certification as an 
externally imposed regulation to protect market shares. Hence, suppliers may express low interest in thorough and costly inspection procedures, giving TPCs reason to reduce certification costs (Jahn, Schramm and Spiller 2005).

As many food sectors are shifting from price- to quality-based competition, TPCs are becoming increasingly important and powerful players in discriminating between higher and lower quality food producers (Henson and Reardon, 2005). Eventually, this trend will likely create larger and more powerful TPCs whose self-interest in profit-maximization, could in turn, affect the functioning of the certification market itself. This justifies a closer scrutiny of both the structure of the TPC markets and its role as a credible quality assurance institution. A critical question is whether the increasing competitive pressure in the certification market will affect the outcome and hence the reliability of the certification process?

\section{ANALYTICAL FRAMEWORK}

The theoretical economic literature investigates the role of market intermediaries, auditors and certifiers in different contexts and markets. This paper proposes a framework to discuss how the evolving market structure of food standard certification may affect the provision of credible market signals. Jahn, Schramm and Spiller (2005), analyse the reliability of certification focusing on the relationship between a standard owner and certifying bodies. In turn, we focus on the relationship among TPCs to gain 
insight into the question of how inter-TPC competition might influence the quality of the certification process.

Previous work has analysed the role of intermediaries as agents disclosing otherwise private information and at the impact of market structure on its effectiveness. Our framework illustrates the structure of private, business-to-business certification, such as the EurepGAP food standard or those emerging from the ISO 9000 standard family. Assuming a private standard system Figure 1 illustrates the institutional structure of a third-party certification system where the standard owner establishes an accreditation system to guarantee and streamline the flow of quality information through certification from producers upstream to the retail market downstream.

Assuming a retail-owned standard, standard requirements are likely to be imposed on all suppliers. Thus, a producer or processor, aiming to enter a contractual relationship, must clearly demonstrate standard compliance which usually requires supplier certification by a third party. A certificate is issued by the TPC based on established rules laid down and reviewed by the standard owner. TPCs in turn have to prove their eligibility to conduct inspections through ISO 65/EN 45011 standard accreditation. Eventually, it is the standard ownerôs responsibility to oversee the development, monitoring and ultimate control of applicable procedures. 
FIGURE 1. Schematic Structure and Competitive Relationships of the

\section{Certification Market}

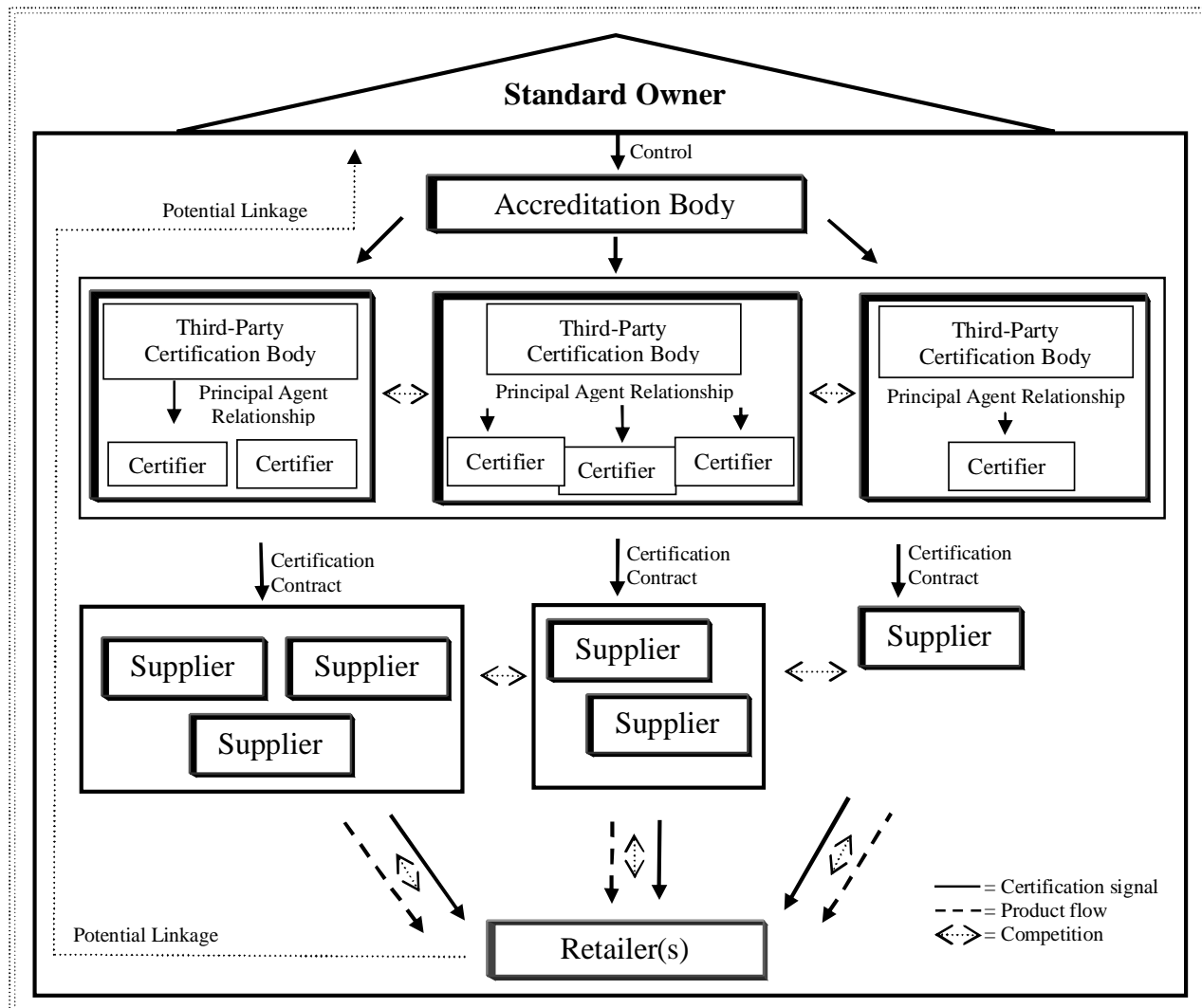

Source: Authorôs own compilation.

As the majority of private food safety and quality schemes are based on ISO 9000 standards, TPCs are offering market based inspection and certification services. Depending on the nature and scope of the standard, the costs of certification and associated inspection routines might be significant (Nadvi and Waeltring, 2002). Moreover, leading accredited TPC bodies like Société Générale de Surveillance (SGS), Det Norske Veritas (DNV), Moodyôs or Integra which provide certification services 
internationally, might sub-contract smaller national companies to conduct certification in their name.

While a standard owner aims at the highest possible assurance level, the dynamics of the TPC market may affect this goal. In fact, individual certifiers that are sub-contracted to become agents of larger certification bodies may pursue deviant principles and certify products or processes that do not meet standard requirements. Furthermore, as Tirole (1986) suggests, collusion among TPCôs and/or retailers and suppliers may compromise their independence and the reliability of the overall certification process. Changes in the competitive structure of the certification market may then have significant implications for both certifiers and associated suppliers.

Carriquiry, Babcock and Carbone (2003) argue that a credible certification scheme is one where high quality products have higher chances of being certified than low quality products. Accurate and independent third-party certification should not only be able to minimize both type I and II certification errors, but also resist any pressure to relax its procedures.

Assuming that accuracy levels increase with firm size and reputation, multinational certifiers may have a competitive advantage in terms of cost and reputation over small and local TPCs. Reputation itself is a function of a TPCQ̂ market experience. Tightening competition may either increase the level of accuracy or reduce it and so affect the amount and reliability of information becoming available (Lizzeri, 1999). Increasing competition 
may prevent reputable firms from relaxing monitoring accuracy, especially if ćontrol-of-controlô mechanisms are effective (Jahn, Schramm and Spiller, 2005). Otherwise, greater competition for certification services contracts may offer incentives to relax grades of accuracy to assure larger market shares. In such case, products that would otherwise fail to comply with a quality standard may pass certification. This, in the long run, would artificially increase compliance rates resulting in overall decreasing product quality, thereby endangering the credibility of third-party certification systems in the food sector. Revolving cases of low quality products, falsely entering the market place regardless of quality assurance systems in place (spoiled meat in Germany), prove the actuality of this argument (Deutsche Welle, 2005).

While each TPCs must demonstrate their independence and accuracy of procedures to obtain accreditation, once this threshold is surpassed, TPC start competing for firms seeking certification services. Insofar as there are a limited number of firms seeking certification for their products or processes and TPC may not need to demonstrate their independence status, stringency could decrease. 


\section{DATA, EMPIRICAL MODEL and RESULTS}

To illustrate cause and affect of increased competition between TPCs in modern supply chain systems, this section presents case study evidence based on EurepGAP, one of main global standards for the certification of agricultural and food products. We focus on EurepGAPôs fruit and vegetable standard because it is the origin of the EurepGAP system. In order to become a EurepGAP accredited certifier, TPCs have to be accredited according to EN 45011 or ISO65 norms. These norms state that TPCs should be independent, impartial, and confidential and have integrity (EurepGAP, 2006). Currently, EurepGAP recognizes over 100 control bodies in more then 70 countries. These compete to certify producers seeking contracts with retailers. From data available through EurepGAPôs website, it becomes apparent that multi-national certification bodies compete with a large number of smaller certifiers that operate in single countries or regions. EurepGAP allows sub-contracting of its global fruit and vegetable standard.

\section{Data Set}

The data used in this analysis is partly obtained directly from EurepGAPQ̂ website (EurepGAP 2006). EurepGAP publishes and updates comprehensive information relating to the approval of TPCs for EurepGAPQ̂ quality assurance system certification that have applied for accreditation under the EN 45011 or ISO65 norms. The available 
information covers currently approved and operating certification bodies in over 100 countries including detailed firm information together with dates of firmôs application and final EurepGAP accreditation (EurepGAP, 02/2007). Information on the specifics of the fruit and vegetables sector in countries where the EurepGAP standard is applied is obtained from FAOSTAT (FAO 2007).

\section{Empirical Model}

A nested panel-model approach is used to analyse the impact of changing market structure in EurepGAPôs certification of fruits and vegetables on the level of inter-TPC competition in a cross-section of over 100 accredited certifiers in 28 countries in the year 2006. The number of competing EurepGAP TPCs involved in the certification of fruits and vegetables in country $i$ is regressed on a number of structural and market specific parameters that are assumed to have an impact on inter-TPC competition. Table 1 presents definitions and descriptive statistics of the dependent and independent variables. The following nested panel model is specified:

Comp_Cert ${ }_{i t}^{j}=\alpha_{0}+\alpha_{1}\left(\right.$ Time_of_Entry $\left._{i t}\right)+\alpha_{2}\left(\right.$ Activity $\left._{i t}\right)+\alpha_{3}\left(\right.$ SHARE_VEGGIE $\left._{i t}\right)$

$+\alpha_{4}\left(\right.$ SHARE_FRUITS $\left._{i t}\right)+\alpha_{5}\left(E X P_{-}\right.$AGRI $\left._{i t}\right)+\alpha_{6}\left(E X P_{-}\right.$FOOD $\left._{i t}\right)+\alpha_{7}(S G S)$

$+\alpha_{8}($ AMERICAS $)+\alpha_{9}($ EUROPE $)+\varepsilon_{i t}$

Comp_Cert is the dependant variable and denotes the number of accredited EurepGAP TPCs $\mathrm{j}$ that compete for certification contracts in the fruit and vegetable sector in country i. The errors $\stackrel{\cup}{t}_{t}$ are assumed to be 
normally distributed with mean zero. Time_of_Entry represents the month and year of entry of a TPC into the EurepGAP system. As an increasing number of TPCs around the world apply for EurepGAP accreditation, we hypothesize that a later market entry entails higher competitive pressure as the number of incumbent certifiers increases. Activity is a proxy of a TPC $\hat{\theta}$ economies of scale denoting the number of countries in which the company certifies fruits and vegetables for EurepGAP.

TABLE 1. Definitions of Variables and Sample Statistics Table

\begin{tabular}{|c|c|c|c|}
\hline Variables & Variable Description & Mean & $\begin{array}{l}\text { Standard } \\
\text { Deviation }\end{array}$ \\
\hline \multicolumn{4}{|c|}{ Dependent Variable } \\
\hline Comp_Cert & & 8.58 & 5.87 \\
\hline \multicolumn{4}{|c|}{ Explanatory Variables } \\
\hline Time_of_Entry & $\begin{array}{l}\text { Month and year of EurepGAP } \\
\text { accreditation }\end{array}$ & 8.27 & 4.67 \\
\hline Timelag & $\begin{array}{l}\text { Time gap between a TPC } \hat{\mathbf{s}} \text { application } \\
\text { and EurepGAP approval }\end{array}$ & 2003.64 & 1.57 \\
\hline Activity & $\begin{array}{l}\text { Number of countries } \mathrm{i} \text { in which TPC j } \\
\text { certifies product }\end{array}$ & 12.87 & 11.53 \\
\hline Share_Veggie & 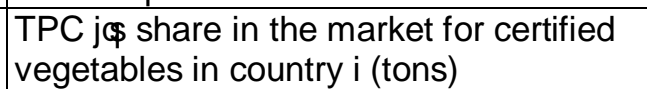 & 821.15 & 3230.50 \\
\hline Share_Fruits & $\begin{array}{l}\text { TPC jôs share in the market for certified } \\
\text { fruits in country } \mathrm{i} \text { (tons) }\end{array}$ & 0.24 & 0.27 \\
\hline Exp_Agri & $\begin{array}{l}\text { Country î̂s value of agr. exports per ton } \\
\text { of vegetable and fruit produced in } 2006\end{array}$ & 15694 & 16960.18 \\
\hline Exp_Food & $\begin{array}{l}\text { Country î̂s value of food exports per ton } \\
\text { of vegetable and fruit produced in } 2006\end{array}$ & 13645 & 14559.73 \\
\hline SGS & $\begin{array}{l}\text { Presence of global TPC player SGS in } \\
\text { country } \mathrm{i}\end{array}$ & 0.73 & 0.44 \\
\hline Americas & $\begin{array}{l}\text { Geographical dummy variable North } \\
\text { and South American countries }\end{array}$ & 0.13 & 0.33 \\
\hline Europe & $\begin{array}{l}\text { Geographical dummy variable } \\
\text { European countries }\end{array}$ & 0.72 & 0.44 \\
\hline
\end{tabular}


As can be seen from Table 1 the average TPC certifies produce in around 13 countries. However, the standard deviation indicates a large bandwidth. From the dataset, we can identify TPC $\hat{Q}$ active in only a single country and global players $\ddot{i}$ like SGS $і ̈$ that certify produce for EurepGAP in over 35 countries. It is assumed that large-scale TPCô have a competitive advantage over smaller ñnationalò certifiers due to differences in certification costs and reputation assets. In addition, multinational companies that are diversified across many markets will be less affected by increased competitive pressure in a single market. We hypothesize a negative impact of Activity on the level of competition.

Share_Veggie and Share_Fruit describe TPC jôs share in country iôs market for certified fruits and vegetables, respectively. With increasing market shares individual certifiers are assumed to face lower competitive and cost pressure, as the underlying market structure deviates toward more oligopolistic structures and finally a monopoly where a single TPC accounts for all certified product.

Exp_Agri and Exp_Food are proxies for the export orientation of country $i$ with respect to the value of its overall exports of agricultural and processed foods, relative to the total size of its fruit and vegetable sector. We assume that an increasing share in international fruit and vegetable market positively affects country iôs involvement in the EurepGAP standard. Hence, we hypothesize positive signs for these variables. 
TPCô like SGS are among the global market leaders in the certification and quality assurance for food stuffs. The variable $S G S$ equals one for countries in which this TPC conducts EurepGAP standard certification and is zero for all other countries. The presence of SGS in country $i$ is assumed to hinder market entry of smaller TPCs and therefore results in less competition in these markets. We expect a negative coefficient.

Americas and Europe are dummy variables depicting the geographical regions South America and Europe. The data identifies South America and Europe $\ddot{i}$ the origin of EurepGAP $\ddot{i}$ as areas of major certification activity. We hypothesize that these regions show higher levels of competition among EurepGAP certification contracts.

Table 2 presents the panel model estimates. Among several model specifications Exact-Maximum Likelihood Estimators (ExactML), corrected for first-order serial autocorrelation revealed the best results based on the Schwarz-Bayesian Information Criterion (SBIC). Statistically insignificant F-tests could not reject the null hypothesis of ExactML over a fixed-effects model specification at the 95-percent level. The nested panel model estimates are generally well behaved. 
TABLE 2. Explaining Inter-TPC Competition in the International EurepGAP

\section{System for Fruits and Vegetables ${ }^{\mathrm{a}}$}

\begin{tabular}{|c|c|}
\hline Variables & Estimates $^{D}$ \\
\hline Year of Entry & $\begin{array}{c}0.006^{\star * \star} \\
(0.00) \\
8.43\end{array}$ \\
\hline Activity & $\begin{array}{c}-0.208^{\star \star \star} \\
(0.03) \\
-5.99\end{array}$ \\
\hline Market Share Vegetables & $\begin{array}{c}0.0001 \\
(0.00) \\
-0.97\end{array}$ \\
\hline Market Share Fruit & $\begin{array}{c}-0.003^{\star \star \star} \\
(0.00) \\
-2.86 \\
\end{array}$ \\
\hline Export Orientation Agricultural Products & $\begin{array}{c}-0.093^{* * *} \\
(0.03) \\
-3.60\end{array}$ \\
\hline Export Orientation Foods & $\begin{array}{c}0.094^{* * *} \\
(0.02) \\
3.62\end{array}$ \\
\hline Presence of SGS & $\begin{array}{c}0.724 \\
(1.03) \\
0.70\end{array}$ \\
\hline South America & $\begin{array}{c}-4.057^{\star \star *} \\
(1.54) \\
-2.62 \\
\end{array}$ \\
\hline Europe & $\begin{array}{l}-0.801 \\
(1.39) \\
-0.57 \\
\end{array}$ \\
\hline $\begin{array}{l}\text { Rho } \\
\text { Test Statistics: }\end{array}$ & $\begin{array}{c}0.12 \\
\text { LogL:-864.05 } \\
\text { DW: } 1.34 \\
\text { R2: } 0.496\end{array}$ \\
\hline
\end{tabular}

${ }^{a}$ Dependent variable: Number of competing TPC $\hat{\mathbf{s}}$ in country $\mathrm{i}$.

${ }^{b}$ ExactML random effect estimates of elasticities corrected for serial correlation. tstatistics and standard errors (in parentheses) computed with White $\hat{\boldsymbol{s}}$ heteroscedasticity-consistent standard errors.

${ }^{* * *}$, and " statistically significant at the 99\%-, 95\%-and 90\%-level, respectively.

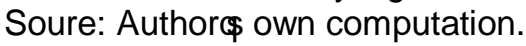

\section{Empirical Results}

Our results show a relative competitive advantage of larger and more diversified TPCs. As indicated by the variables Activity and Share_Fruit 
increasing market diversification, in terms of the number of countries TPC $\mathrm{j}$ certifies product in, greater market shares result in less competitive pressure from competitors. While this result is significant for EurepGAPQ̂ fruit standard, the coefficient for Share_Veggie is not significant.

The variable Year_of_Entry provides valuable insight into the relation between market entry and the level of competition. EurepGAPôs recognition and importance as a global quality assurance system in food trade has rapidly increased since its inauguration in 1997. The positive sign indicates that over time, rising numbers of accredited EurepGAP certifiers have significantly raised the level of competition among certification bodies and across countries.

The internationalization of trade in foods and agricultural products in recent years has been a driving factor of increased importance of international standardization and certification systems as is EurepGAP. Increasing information asymmetries and uncertainty about product quality and food safety in todayôs global food trade makes a reliable certification of food products vital. This is particularly important for many developing countries that strive to gain better market access to Europeôs and North Americâ̂ high-value markets. Our model results reveal that rising levels of export orientation in processed foods, relative to the amount of fruit and vegetable production in a country, positively affects the number of competing TPCs in these sectors. Interestingly, the exact opposite seems to 
be the case with respect to a countryôs degree of commodity export orientation. Larger shares of commodity exports have a significant negative effect on a countryôs penetration by food quality standards such as EurepGAP.

The variable $S G S$, as hypothesized earlier, assumes a negative effect of incumbent reputation and economies of scale on the competitiveness of new TPCs in the EurepGAP system. However, we can not infer much more than the direction of change as the coefficient for $S G S$ is insignificant.

Finally, our results provide insight into differences in inter-TPC competition in different geographical markets. Our data reveals that EurepGAP plays a major role in the fruit and vegetable sectors of many South American countries. Another focus of EurepGAP, of course, is Europe. Against the hypothesized effect, both variables show negative coefficients. TPCs operating in South American countries face significantly less competitive pressure from rival TPCs compared to other world regions involved in fruit and vegetable trade. The same effect seems to hold for Europe, but remains insignificant.

\section{CONCLUDING REMARKS}

Third-party certifiers are playing an increasing role in international quality food markets as consumers increasingly demand clear and credible signals with regards to the quality and safety of foods. Global food procurement and trade entail increasing uncertainty and information 
asymmetries. As competition in many food markets is shifting from a firm to a multi stakeholder supply-chain configuration, a considerable number of private TPCs have emerged to provide product and process certification of quality attributes used in product differentiation in todayô globalized food system.

Previous research has addressed the importance of TPCs as a private institution that facilitates the reduction of uncertainties related to information asymmetries in credence food quality and safety attributes. One of the main arguments raised in the literature is that to properly fulfil their role, TPCs must remain independent and stringent [Tanner, 2000; Deaton, 2004; Busch et al., 2005]. This paper maintains that the accuracy of private TPCs might be affected by the level of competition among rival certification providers. Namely that, with increasing numbers of competitors in a market, the level of quality and safety assurance provided under a certain standard might be much reduced.

Based on panel data of EurepGAPôs global standard for the certification of fruits and vegetables, our analysis provides empirical evidence and valuable insight into the competitive structures among the rapidly increasing number of EurepGAP accredited certifiers. Moreover, our results are intended to stimulate the ongoing discussion on the role of private thirdparty certification of agricultural and processed food products as an important means to assure the quality and safety of consumer foods. 
Finally, this study emphasises the need for more detailed data to facilitate research on the differences between certified product and residual commodity market segments. Such information is vital to the better understanding of the implications of private food standards, such as EurepGAP, the British Retail Consortium (BRC) or Safe Quality Food (SQF), have on the performance of todayôinternational food supply chains.

\section{REFERENCES}

Barkema, A. \& M. Drabenstott (1995). The many paths of vertical coordination: Structural implications for the US food system. Agribusiness 11 (5), 483-492.

Busch, L., D. Thiagarajan, M. Hatanaka, C. Bain, L. G. Flores \& M. Frahm (2005). The Relationship of Third-Party Certification (TPC) to Sanitary/Phytosanitary (SPS) Measures and the International Agri-Food Trade: Final Report. Raise SPS Global Analytical Report \#9, Washington D.C., USAID.

Busch, L. \& C. Bain (2004). New! Improved? The Transformation of the Global Agrifood System. Rural Sociology, 69 (3), 321 ï 346.

Carriquiry, M., B. A. Babcock \& R. Carbone (2003). Optimal Quality Systems for Agricultural Outputs. 03-WP 328 March 2003 CARD, Iowa State University, Ames. 
Caswell, J. A., M. E. Bredahl \& N. H. Hooker (1998). How Quality Management Metasystems Are Affecting the Food Industry. Review of Agricultural Economics, 20 (2), 547-557.

Deaton, J. (2004). A theoretical framework for examining the role of thirdparty certifiers. Food Control, 15, 615-619.

Deutsche Welle (2005). Germany to Tighten Controls on Spoiled Meat.

Deutsche Welle Radio Dec. 8, 2005, www.deutsche-welle.de/dw/article/ 0,2144,1808099,00.html. (assessed Oct.. 26, 2007).

EurepGAP (2006). General Regulations for Fruits and Vegetables. Version 2.1 (update September 25, 2006). Available at:

http://www.eurepgap.org/fruit/ Languages/English/ documents.html.

FAO (Food and Agriculture Organization) (2007). FAOSTAT, Global Agricultural Production, All Data. Available at: http://faostat.fao.org (assessed Jan. 17, 2007).

Fulponi, L. (2006). Private voluntary standards in the food system: The perspective of major food retailers in OECD countries. Food Policy, 31(1): 1-13.

Hatanaka, M., C. Bain \& L. Busch (2005). Third-party certification in the global agrifood system. Food Policy, 30 (3), 354-369.

Henson, S. (2006). The Role of Public and Private Standards in Regulating International Food Markets. Paper presented at the IATRC summer symposium "Food Regulation and Trade: Institutional Framework, 
Concepts of Analysis and Empirical Evidence", Bonn, Germany, May 2830, 2006, Department of Food, Agricultural and Resource Economics, University of Guelph, Guelph, Canada. Available at: www.agp.unibonn.de/iatrc/iatrc_program/Session\%204/Henson.pdf (accessed Nov. 15, 2006).

Henson, S. \& T. Reardon (2005). Private agri-food standards: Implications for food policy and the agri-food system. Food Policy, 30 (3), 241-253. Henson, S. \& J. Northen (1998). Economic Determinants of Food Safety Controls in Supply of Retailer Own-Branded Products in the United Kingdom. Agribusiness, 14 (2),113-126.

Lizzeri, A. (1999). Information Revelation and Certification of Intermediaries. Rand Journal of Economics, 30 (2), 214-231.

Manning, L. \& R. N. Baines (2004). Effective management of food safety and quality. British Food Journal, 106(8/9): 598-606.

McCluskey, J. J. (2000). A Game Theoretic Approach to Organic Foods: An Analysis of Asymmetric Information and Policy. Agricultural and Resource Economics Review, 29 (1), 1-9.

Meuwissen, M. P. M., A. G. J. Velthuis, H. Hogeveen, \& R. B. M. Huirne (2003). Technical and economic considerations about traceability and certification in livestock production chains. In: A.G.J. Velthuis, L.J. Unnevehr, H. Hogeveen and R. B. M. Huirne (eds.). New approaches to food safety economics, Wageningen: Kluwer Academic Publishers, 41-54. 
Nadvi, K. \& F. Waeltring (2002). Making Sense of Global Standards.

INEF-Report 58, Institut fuer Entwicklung und Frieden, Gerhard-

Mercator University Duisburg, 48p.

Tanner, B. (2000). Independent assessment by third-party certification bodies. Food Control, 11, 415-417.

Tirole, J. (1986). Hierarchies and Bureaucracies: On the Role of Collusion in Organisations. Journal of Law, Economics and Organization, 2 (2), 181-214. 